\title{
Analysis of the assessment methods of reinforced concrete beams in fire conditions proposed by NBR 15200
}

\author{
Análise dos métodos de verificação de vigas de \\ concreto armado em situação de incêndio propostos \\ pela NBR 15200
}
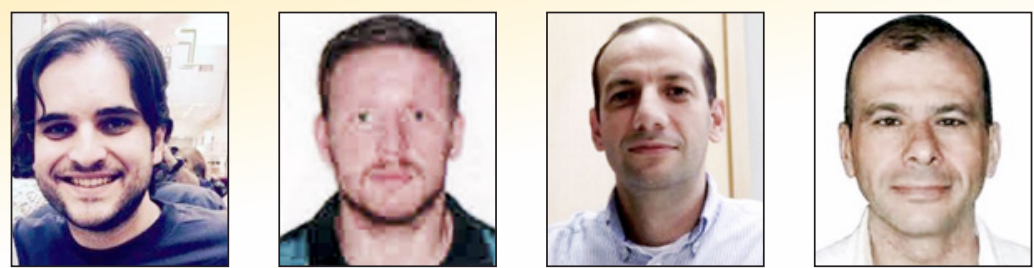

F. L. BOLINA a

fabriciolb@unisinos.br

B. BAQUES a bennobackes@gmail.com

B. F. TUTIKIAN a

bftutikian@unisinos.br

J. P. C. RODRIGUES b jpaulocr@dec.uc.pt

\begin{abstract}
In Brazil, reinforced concrete structures designed based on NBR 6118 [1] must be assessed in fire conditions through NBR 15200 [2], which proposes multiple test methods. Concerning beams, this standard offers the tabular and simplified methods as possible choices. This study aimed to compare these two methods by applying their principles to isostatic and hyperstatic beams with section of $20 \times 50 \mathrm{~cm}$, designed at room temperature according to NBR 6118 [1]. The temperature distribution along sections was obtained by means of a software program. The results from this study indicated that the simplified method yielded higher fire-resistance ratings (FRR) in $75 \%$ of cases, although not surpassing the tabular method by 30 minutes. The simplified method allowed an optimization of the results, despite the longer design time.
\end{abstract}

Keywords: reinforced concrete in fire conditions, fire, structural design, NBR 15200.

\section{Resumo}

No Brasil, as estruturas de concreto armado projetadas com base na NBR 6118 [1] devem ser verificadas em situação de incêndio pela NBR 15200 [2], a qual propõe diferentes métodos de verificação. No caso de vigas, tem-se como alternativa o método tabular e o simplificado, entre outros. O objetivo deste artigo foi realizar uma comparação entre ambos os métodos, por meio da aplicação de seus critérios em vigas isostáticas e hiperestáticas, de seção $20 \times 50 \mathrm{~cm}$, projetadas à temperatura ambiente pela NBR 6118 [1]. A distribuição de temperatura nas seções foi obtida por programa computacional. Os resultados apontaram que, no caso estudado, o método simplificado apresentou tempos de resistência ao fogo (TRF) superior em $75 \%$ dos casos, mas não superiores a 30 minutos em relação ao método tabular. O método simplificado permitiu otimizar resultados, apesar do maior tempo para o dimensionamento.

Palavras-chave: concreto armado em situação de incêndio, incêndio, projeto estrutural, NBR 15200.

UNISINOS, Civil Engineering. São Leopoldo, RS, Brazil,

Universidade de Coimbra, Civil Engineering, Coimbra, Portugal.

Received: 17 Dec 2017 • Accepted: 17 May 2018 • Available Online: 23 Nov 2018

This is an open-access article distributed under the terms of the Creative Commons Attribution License 


\section{Introduction}

Mechanical and physical properties of structural elements of reinforced concrete vary according to temperature. When the structure is exposed to fire, temperature increases and alters mechanical and thermal properties of the materials composing the structure [4]. These changes cause loss of strength and adherence between cement and aggregates, as well as cracking and spalling [5], which may lead to local or global collapse [6] and therefore must be contemplated during the design stage.

Upon being exposed to fire, beams that are heated only on the bottom surface can suffer deformations from mechanical degradation and thermal expansion of the materials that comprise them $[15,16]$. Non-uniform thermal expansion brings about differential expansion to the piece which moves the line of action of the horizontal hyperstatic reaction below the neutral axis of its cross-section if stopped by the constraint provided by the supports, hence causing bending moments contrary to positive flection. The effect is triggered by mechanical degradation of the piece's heated area. The higher heating of the beam's bottom half, directly exposed to the burning environment, in conjunction with the lower heating of the other half, thermally protected along the intersection with the slab, makes the mechanical properties of the less heated part undergo transformations milder than the others [8]. Such fact promotes an uneven redistribution of stresses in the section of the beam, which starts to present different tensile strengths in the multiple layers that compose it.

For design, the required fire-resistance rating (TRRF) is given by NBR 14432 [3]. The criteria for the structure to reach this condition are given by NBR 15200 [2], inspired by EN1992-1-2 [21], through the tabular, analytical, simplified, advanced and experimental methods of assessment of reinforced concrete structures. The methods differ from each other according to the approach chosen, which can be more or less complex as more refinement is sought. The analytical method cannot be applied to reinforced concrete beams, as it is effective for columns only. The tabular method is the easiest to apply, despite being the most conservative and able to yield anti-economical values with a degree not yet measured. The simplified and advanced methods are more complex and precise [7]. The experimental methods are costly and face limitations with regards to laboratory test furnaces [9].

When dimensioning reinforced concrete beams by the tabular method, [19] points out that the following hypotheses are admissible: (a) beams under slabs, which promote their heat on three surfaces only, (b) moment redistribution, as for continuous beams, and (c) critical temperature of bottom longitudinal reinforcements equals to $500^{\circ} \mathrm{C}$. In order to define the strength reduction factors of materials subjected to high temperatures, [19] states that NBR 15200 relied on old correlations, presented in Equations (1) for steel, depicted as graphs in the standard. The strength reduction factors of reinforcements are used in the simplified and advanced methods as well. The design criteria took inspiration from Eurocode 2, whereas some adjustments and simplifications were adopted to fit the Brazilian reality.

$\mathrm{k}_{\mathrm{s}}(\theta)=1.0$ for $20^{\circ} \mathrm{C}<\theta<350^{\circ} \mathrm{C}$

$\mathrm{k}_{\mathrm{s}}(\theta)=1.0-0.4(\theta-350) / 150$ for $350^{\circ} \mathrm{C}<\theta<500^{\circ} \mathrm{C}$

$\mathrm{k}_{\mathrm{s}}(\theta)=0.61-0.5(\theta-500) / 200$ for $500^{\circ} \mathrm{C}<\theta<700^{\circ} \mathrm{C}$

$\mathrm{k}_{\mathrm{s}}(\theta)=0.1-0.1(\theta-700) / 500$ for $700^{\circ} \mathrm{C}<\theta<1200^{\circ} \mathrm{C}$
As simplification, NBR 15200 [2] allows the calculation stresses in fire conditions to be $70 \%$ of the calculation stresses at room temperature, disregarding wind effects. The principle is valid for analyzing isolated elements that could ignore the effects of thermal expansion that occur during the fire [10]. NBR 15200 also allows the designer to disregard the stresses from thermal expansions, because the increase of temperature makes the pieces lose toughness and increases their plastic adaptability [7].

Therefore, this study aimed to compare the tabular and simplified methods proposed by NBR 15200 [2], applying them to two hypothetical beams: one hyperstatic and the other isostatic. The tabular was expected to be conservative, but comparing it with the simplified method, which takes longer and requires computer-aided simulations that are more specific and sophisticated, makes it possible to understand its degree of conservatism and then contribute to the viability of alternative methods minding the practical results obtained.

\subsection{Justification}

Estimating fire resistance of elements by means of tabulated data is simple, although this procedure faces limitations such as its application to elements with preset sizes and design criteria [11]. Besides its frequent inability to support real conditions of load, dimensioning and behavior of structures [12], this procedure can yield results that are less economical than more sophisticated methods. Some authors recognize that tabular methods do not pose as the best technical solution for disregarding specific needs inherent to structures and protection systems that may be present $[9,12]$. In spite of being methods of fast to application, their conservatism is necessary and justifiable.

According to [4], the determination of fire resistance of elements through mathematical methods has been gaining acceptance for being less costly than experimental tests in real scale while giving answers that are more interesting than those of tabular methods due to the addition of some principles of design at room temperature. It is then necessary to understand the degree of conservatism inherent to the tabular method for assessment of reinforced concrete beams in fire conditions proposed by NBR 15200 [2], comparing it to other more sophisticated methods of the same standard, like the simplified method. The results can show indirectly that it is possible to use computer tools and the criteria of more sophisticated designs.

\section{Method}

An isostatic simply-supported beam and a hyperstatic beam were analyzed. These measures were adopted because NBR 15200 [2] consents the degree of elasticity of elements within design propositions. Considering that the structural design in fire conditions regards a verification, the beams were dimensioned at room temperature first and then assessed in this exposure condition under the tabular and simplified methods of NBR 15200 [2]. The Abaqus $\mathbb{R}$ software suite (version 6.11) was therefore used to determine the temperature distribution along sections.

The top face of the beam, at the height of the pavement, was considered adiabatic. It is then supposed that temperatures concentrate on the floor of the building and on the slab around the beam, which must be evaluated through NBR 15200 [2], hence 
Table 1

Mechanical parameters admitted

\begin{tabular}{ccc}
\hline Parameter & Steel & Concrete \\
\hline Poisson's ratio & 0.30 (NBR 6118) & 0.15 (NBR 61 18) \\
Elastic modulus & 210 (NBR 6118) & 25 (NBR 61 18) \\
(GPa) & Annex E & Annex C of \\
Thermal & of NBR 14323 & NBR 15200 \\
conductivity & Annex E & Annex C of \\
Specific heat & of NBR 14323 & NBR 15200 \\
Density $\left(\mathrm{kg} / \mathrm{m}^{3}\right)$ & $7850($ NBR 6118) & $2400($ NBR 6118) \\
\hline
\end{tabular}

fulfilling the requirements of mechanical strength (S), tightness $(T)$ and thermal insulation (I), and compartmentalizing the room. It was also assumed that the slab thermally protects part of the lateral face of the beam at their intersection point. Thus, the top reinforcements of the beam are thermally protected, as the coefficient $\mathrm{C} 1$ lateral $(\mathrm{C} 1 \mathrm{l})$ related to them is theoretically infinite. The other principles adopted in this study are described as follows.

\subsection{Mechanical parameters}

Table 1 presents the mechanical parameters that were admitted for the design of beams.

\subsection{Parameters and design criteria}

The beams were dimensioned for all NBR 6118 [1] durability design classes, as reinforcement cover and concrete strength interfere with the fire-resistance rating of the elements. The design parameters adopted are presented in Table 2.

The structural design of beams did not consider the contribution of the slab. They were calculated as rectangular. The beams were dimensioned at the bending moment seeing that they usually break as a result of bending rather than shearing when on fire, as stressed by [17] and noted in the experimental study of [16].

The calculation criteria were based on the hypotheses of flat sections, absolute adherence between steel and concrete and null participation of tensile stresses on concrete. The rectangular sections of the beams were designed with simple reinforcements which were rightfully satisfied by the analysis of relative depth of the neutral axis, and the application of the criterion of stress redistribution.

The procedure admitted for room temperature dimensioning has been deduced by equilibrium of forces in [18], and is presented in
Table 2

Parameters of design as per NBR 6118

\begin{tabular}{ccc}
\hline Exposure class & $\begin{array}{c}\mathbf{f}_{\mathrm{ck}} \\
(\mathrm{MPa})\end{array}$ & $\begin{array}{c}\text { Nominal cover } \\
(\mathbf{m m})\end{array}$ \\
\hline I - Weak & 20 & 25 \\
II - Mild & 25 & 30 \\
III - Strong & 30 & 40 \\
IV - Very strong & 40 & 50 \\
\hline
\end{tabular}

Equations (1), (2) and (3), whereas Equation (2) details the reduced bending moment $\mu$ admited, with concrete strength reduction factor $\gamma_{f}$ equals 1.40 as per [1]. The relative depth of the neutral axis $\xi$ was defined in Equation (3), minding $\lambda=0.80$, factor which came from simplifications of the parabola-rectangle diagram for compressive stresses that act on the concrete. The area of steel was defined based on Equation (4), with $\gamma_{\mathrm{s}}=1.15$ [1], $\mathrm{b}$ and $\mathrm{d}$ the useful width and height, respectively, of the rectangular section of the beam.

$\mu=\frac{M_{d}}{b d^{2} 0.85 \frac{f_{c k}}{\gamma_{f}}}$

$\xi=\frac{1-\sqrt{1-2 \mu}}{\lambda}$

$A_{s}=\lambda \xi b d \frac{0.85 \cdot \frac{f_{c k}}{\gamma_{f}}}{\frac{f_{y k}}{\gamma_{s}}}$

The calculation procedure for fire conditions was similar to the one at room temperature. It considered a bending moment $M_{d}$ equals to $70 \%$ of the one admitted at room temperature and disregarded the factor $\alpha=0.85$ related to long-duration effects on concrete and the adjustment between values measured for cylindrical specimens and the ones of the finished structure, with strength reduction factors of 1.00, as per [2]. The characteristic strengths of materials, $f_{c k}$ and $f_{y k}$, were multiplied by a reduction factor that varied according to the average temperature of each fire exposure time admitted. These strength reduction factors are defined by [2].

\subsection{Structural calculation modeling}

The study was performed on two reinforcement concrete beams of distinct elastic conditions. The first, isostatic, was modelled as simply supported with a span of $5 \mathrm{~m}$ and linearly distributed load of 20 kN/m, called "Beam B1", as depicted in Figure 1a. The second,

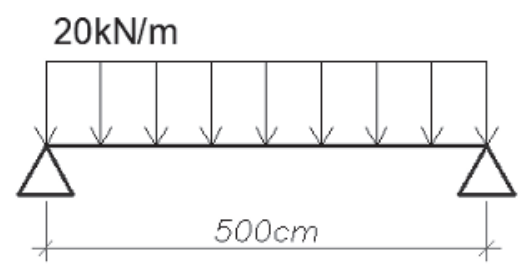

(a)

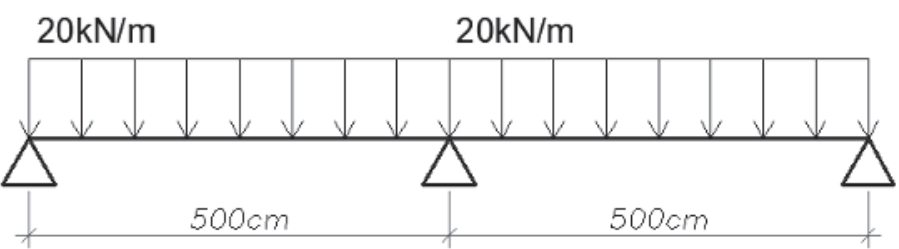

(b)

Figure 1

Calculation model of (a) Beam B1 and (b) Beam B2 

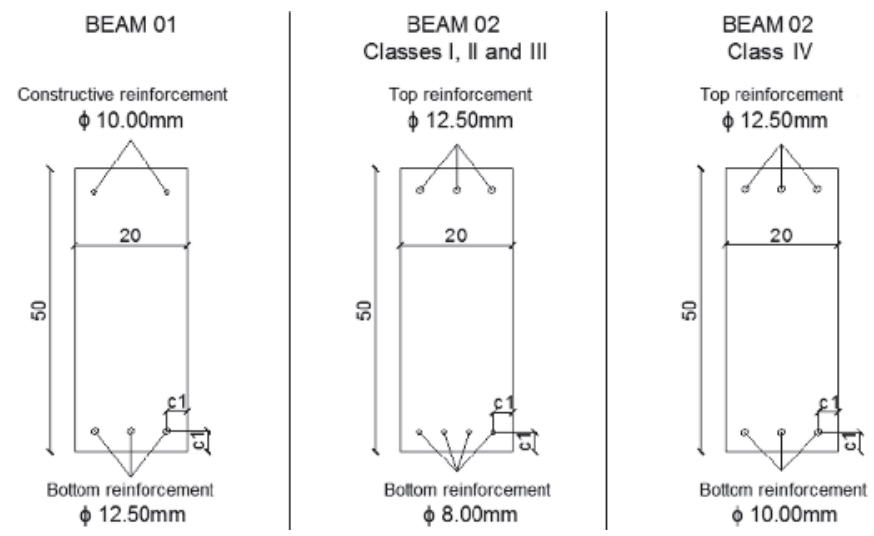

Figure 2

Details of beams B1 and B2 for each exposure class

hyperstatic, was modelled as continuous, with spans of $5 \mathrm{~m}$ and the same load, being entitled "Beam B2" as depicted in Figure $1 \mathrm{~b}$.

\subsection{Nomenclatures and details of elements}

The nomenclature adopted consisted of the number of the beam, in Arabic numerals, followed by the exposure class of NBR 6118 to which it belongs, in Roman numerals. Therefore, B1-I, B1-II, B1III and B1-IV are the names for Beam 1 designed for exposure classes I, II, III and IV respectively. Similarly, B2-I, B2-II, B2-III and B2-IV make up the nomenclature of Beam 2.

Figure 2 presents the sections of beams B1 and B2 according to the dimensioning at room temperature, for durability design classes I to IV of NBR 6118 [1]. For simplification, both positive and negative reinforcements were considered for $\mathrm{B} 2$, which correspond to the segments of higher stress. Stirups with diameter of $5 \mathrm{~mm}$ were admitted in a representative way.

\subsection{Procedure of assessment of beams in fire conditions}

The procedures adopted for assessing reinforced concrete beams at high temperatures through the tabular and the simplified methods are presented as follows.

\section{a) Tabular method}

Determining TRF through this method consisted of comparing the dimensions of the beam designed at room temperature with the minimum thicknesses of C1 (C1req) required by NBR 15200 [2]. Due to there being only one layer of longitudinal reinforcements, the coefficient C1req for beams had to be increased by $10 \mathrm{~mm}$ as noted in section 8.2.1 of NBR 15200 [2], considering that temperature concentrates mainly along the edges of the interior face of the beams. The values of C1req of each TRRF for Beam B1 and Bean B2 admitted interpolations of the tables of NBR 15200 [2]. The $C 1$ req values are presented in Table 3. The width "b" turned out to be insufficient within the criteria of this method on certain occasions.

The TRF of each element was obtained through the tabular method by comparing $\mathrm{C}_{\text {req }}$ with the thickness $\mathrm{C} 1$ defined for the beam designed at room temperature, here called $\mathrm{C} 1_{\text {calc }}$. The thickness value of $\mathrm{C} 1$ regards the distance between the face of the element and the center of the longitudinal reinforcement and is given by Equation (5), where "c" is the cover thickness of the reinforcement, $\varnothing \mathrm{e}$ the diameter of the stirrup, and Øp the diameter of the longitudinal reinforcement.

$C 1=c+\varnothing e+0.50 \varnothing p$

\section{b) Simplified method}

The assessment through this method consisted of comparing the moment of inertia of the section of the beam, admitting strength loss of steel and concrete at high temperatures, with bending moment in fire conditions. In this case, the bending stress of calculation was assumed as $70 \%$ of the one at room temperature as per NBR 15200[2]. The redistribution of moments in fire conditions was admitted for beams B2. This redistribution reduced moment in the span by $25 \%$ and was recalculated based on Equation (6), typifying the criterion practiced by [20]. It was also used at room temperature, although with different safety factors, where "l" is the span of the beam, $M_{S d, f i(r e d)}^{-}$and $M_{S d, f i(r e d)}^{+}$are the negative and positive bending moments of calculation redistributed in fire conditions, and $\mathrm{p}_{\mathrm{d}, \mathrm{fi}}$ is the value of the uniformly distributed load in fire conditions.

$M_{S d, f i(r e d)}^{-}=\frac{p_{d, f i} l^{2}}{2} p_{d, f i} l^{2} \sqrt{\frac{2 M_{S d, f i(r e d)}^{+}}{p_{d, f i} l^{2}}}$

To determine the temperature distribution along sections of the beam, a computer-aided model by finite elements was specified. With the temperature at longitudinal reinforcements and the compressed section of concrete, a strength reduction factor was applied to each material as NBR 15200 [2] recommends. The moment of inertia was thereby recalculated based on the same procedure adopted at room temperature, although using a factor of 1 to weigh strengths instead of the factors of 1.40 and 1.15 for concrete and reinforcements respectively indicated in section 6.2.1 of NBR 15200 [2]. For analyses at high temperatures, the strength of concrete was not affected by the factor $\alpha=0.85$ defined by [1] in the calculations at room temperature, which regard the long-duration effects that act on the structure, set for a lifespan of 50 years, and the difference between strength values defined for specimens and the ones measured for the finished structure. As for high-temperature calculations, the designed load of the structures was equals to $70 \%$ of the one defined at room temperature, in accordance with section 8.1 of NBR 15200 [2].

\section{Table 3}

C1 coefficients required by NBR 15200

\begin{tabular}{ccc}
\hline $\begin{array}{c}\text { RFRR } \\
(\text { min) }\end{array}$ & $\begin{array}{c}\mathbf{C}_{\text {1rea }} \\
\text { Beam B1 }\end{array}$ & $\begin{array}{c}\mathbf{C}_{\text {1req }} \\
\text { Beam B2 }\end{array}$ \\
\hline 30 & 15 & 12 \\
60 & 29.55 & 12 \\
90 & 54.54 & 40.45 \\
120 & 76.40 & 54.09 \\
180 & Insufficient "b" & Insufficient "b" \\
\hline
\end{tabular}


Table 4

Bending moments at room temperature

\begin{tabular}{ccc}
\hline Element & $\begin{array}{c}\text { Positive moment } \\
(\mathrm{kNm})\end{array}$ & $\begin{array}{c}\text { Negative moment } \\
(\mathrm{kNm})\end{array}$ \\
\hline Beam B1 & 62.50 & - \\
Beam B2 & 35.20 & 62.50 \\
\hline
\end{tabular}

\subsection{Criteria admitted for computer-aided analyses}

The exposure temperatures of the beams abided by the ISO 834 curve [13]. The beams were exposed by means of a convective and irradiant flow on the three exposed faces, assuming that the upper face was insulated by the slab (adiabatic). It should be noted that the slab was not considered as an element that contributed to the bending moment of the beam, but as a thermal protection instead. The coefficients of emissivity and convection used were those recommended by NBR 15200 [2]. Upon obtaining the temperatures in the section, a mesh with $3 \mathrm{~cm}$ of side was defined in the analysis. The average temperature of concrete was collected only in the compressed region of the section. The concrete that bore stress was neglected in the calculation.

\section{Results and discussion}

\section{1 'Calculation of the bending moments of design}

The bending moments of calculation used for room-temperature dimensioning are presented in Table 4.

\subsection{Structural detailing}

The correlation between positive bending moment of calculation and positive limiting moment of the section designed (degree of utilization) of beams B1-I, B1-II, B1-III, BI-IV, B2-I, B2-II, B2-III and B2-IV was 88.85; 88.50; 89.64; 90.58; 90.54; 90.83; 92.41; $78.58 \%$ respectively. For the negative moments of beam B2I, B2-II, B2-III and B2-IV, the degree of utilization achieved was $88.85 ; 88.50 ; 89.64$ and $90.58 \%$ respectively. For exposure class $\mathrm{IV}$, three bars of $100 \mathrm{~mm}$ of diameter had to be added to beam B2 in order to achieve the minimum distance between bars required by NBR 6118 [1].

\subsection{Assessment in fire conditions: tabular method}

Table 5 presents the thickness $\mathrm{C} 1$ obtained by calculation and dimensioning of each beam $\left(\mathrm{C}_{\text {calc }}\right)$ at room temperature and the minimum thicknesses of $\mathrm{C} 1\left(\mathrm{C} 1_{\text {reg }}\right)$ required by NBR 15200 [2]. Both coefficients were compared and the resulting fire-resistance time (TRF) was defined.

By comparing cover thicknesses of reinforcements dimensioned at room temperature, and so the coefficients $\mathrm{C} 1$ extracted from the section designed, a comparison with the dimensions proposed by NBR 15200 [2] was performed. For isostatic elements, the beams designed to meet requirements at room temperature can reach a TRRF of up to 90 minutes. As for hyperstatic elements, these can reach up to 120 minutes. When applying the tabular method to the beams of this study, the staticity admitted for the calculation model only has impact if the dimensioning regards exposure classes

\section{Table 5}

FRR attained though the tabular method

\begin{tabular}{|c|c|c|c|c|c|}
\hline Element & $b(\mathrm{~mm})$ & Cover $(\mathrm{mm})$ & $C_{\text {lcalc }}(\mathrm{mm})$ & $\mathrm{C}_{\text {1req }}(\mathrm{mm})$ & FRR (min) \\
\hline Beam B1 - I & 200 & 25 & 36.25 & 29.55 & 60 \\
\hline Beam B1 - II & 200 & 30 & 41.25 & 29.55 & 60 \\
\hline Beam B1 - III & 200 & 40 & 51.25 & 29.55 & 60 \\
\hline Beam B1 - IV & 200 & 50 & 61.25 & 54.54 & 90 \\
\hline Beam B2 - I & 200 & 25 & 34.00 & 12 & 60 \\
\hline Beam B2 - II & 200 & 30 & 39.00 & 12 & 60 \\
\hline Beam B2 - III & 200 & 40 & 49.00 & 40.45 & 90 \\
\hline Beam B2 - IV & 200 & 50 & 59.00 & 54.09 & 120 \\
\hline
\end{tabular}
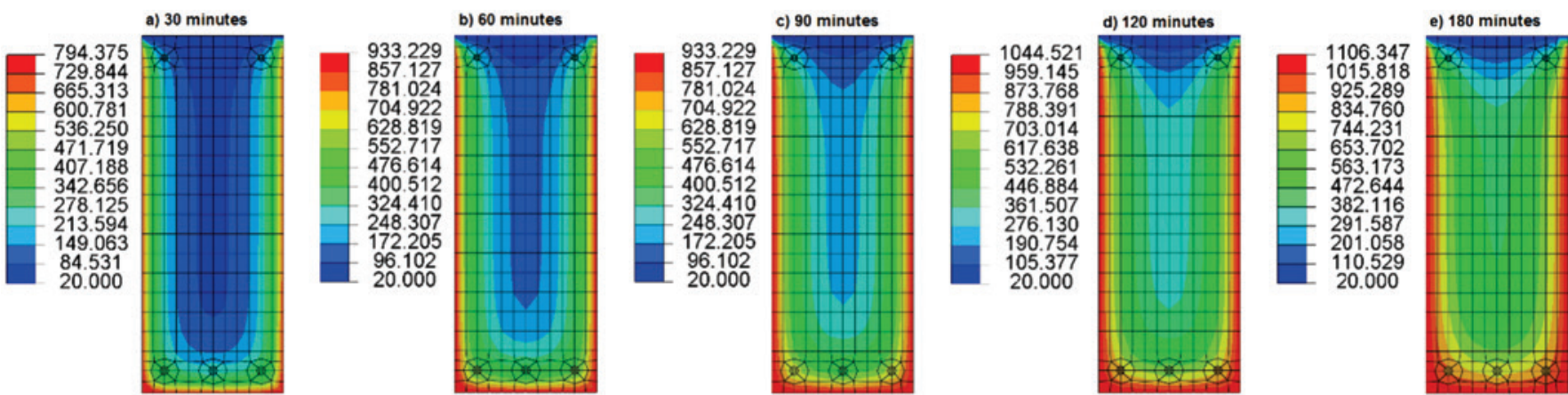

Figure 3

Isotherm B1-I for ratings of (a) 30, (b) 60, (c) 90, (d) 120, and (e) 180 minutes 
III and IV. The beam of classes I and II did not present fire-resistance gains when the staticity was changed.

\subsection{Assessment in fire conditions: simplified method}

The temperatures adopted in the beam assessment calculations, admitted to estimate strength reduction factors of the materials that made composed them, were visually extracted from the isotherms yielded by the Abaqus software suite and are depicted from Figure 3 to Figure 10.

It can be noted, as expected, that the thicker the cover of the reinforcements, the higher the thermal protection provided by the concrete to the steel bars, due to the increase of the factor $\mathrm{C} 1$. This fact must be analyzed with caution though, as the distribution of temperature along sections doesn't depend solely on this
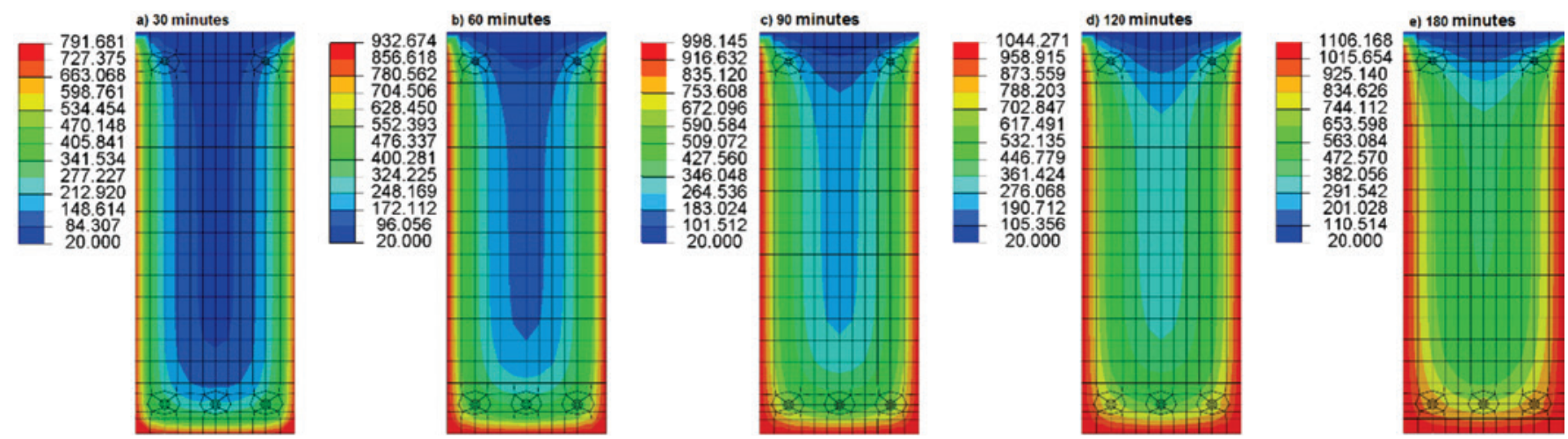

Figure 4

Isotherm B1-II for ratings of (a) 30, (b) 60, (c) 90, (d) 120, and (e) 180 minutes
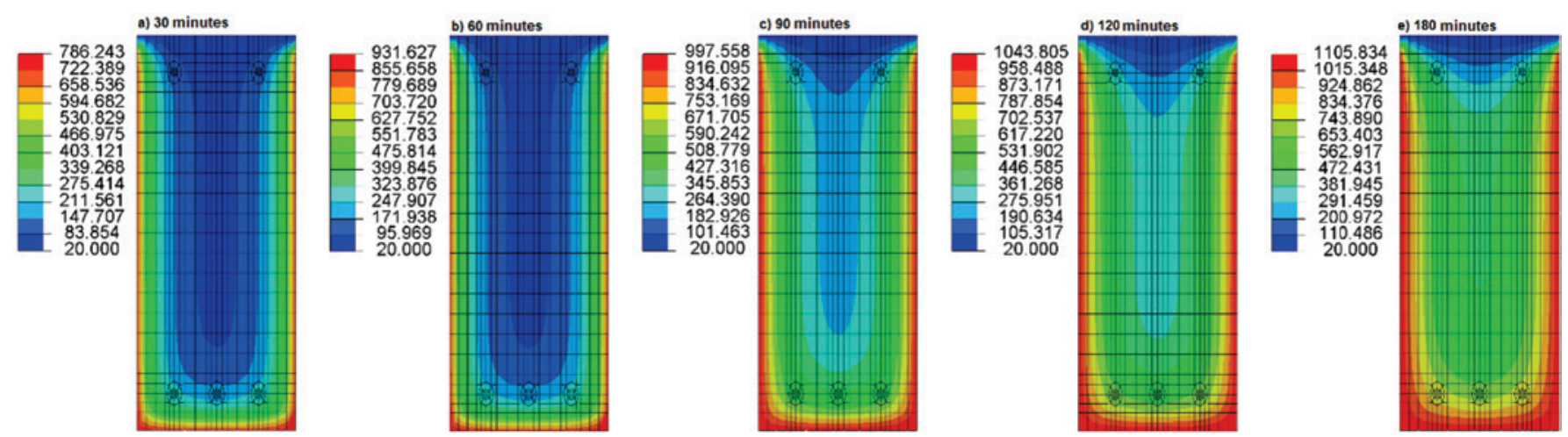

\section{Figure 5}

Isotherm B1-III for ratings of (a) 30, (b) 60, (c) 90, (d) 120, and (e) 180 minutes
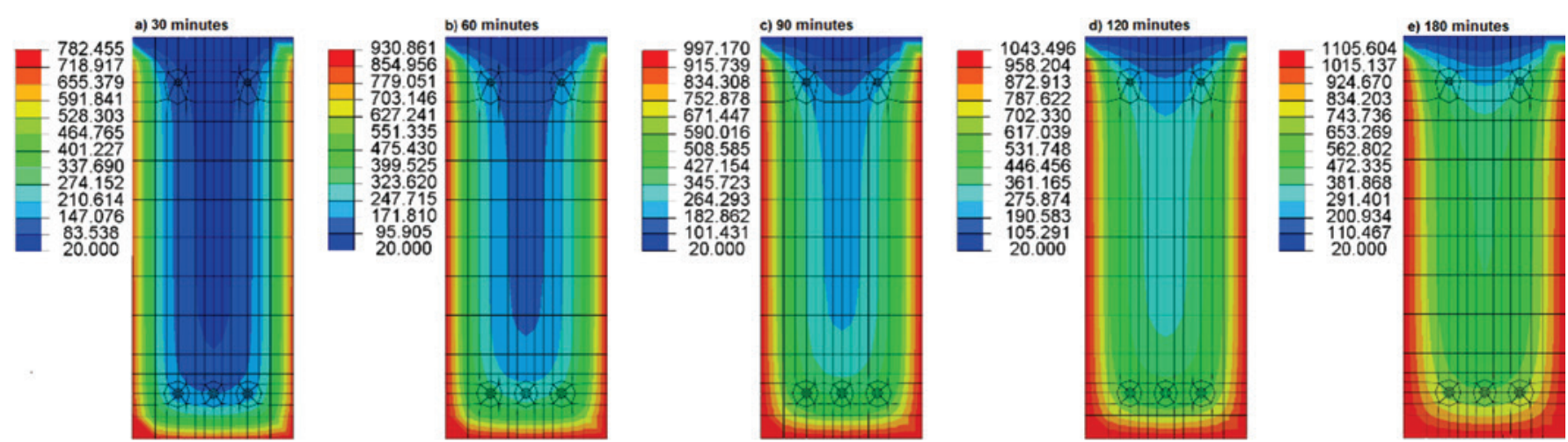

Figure 6

Isotherm B1-IV for ratings of (a) 30, (b) 60, (c) 90, (d) 120, and (e) 180 minutes 


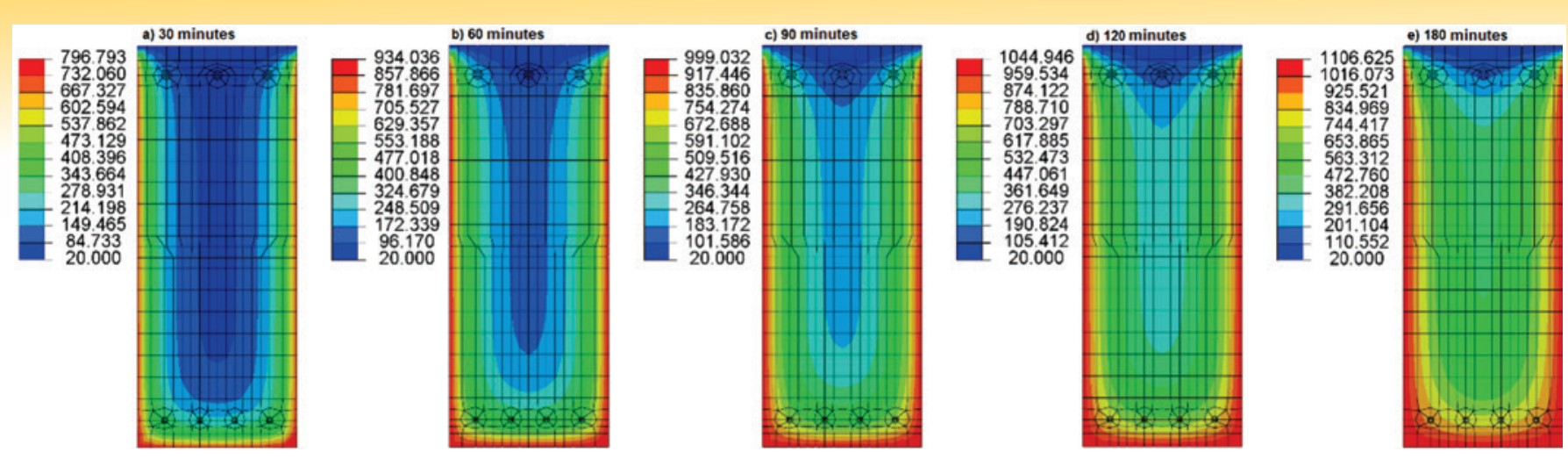

\section{Figure 7}

Isotherm B2-I for ratings of (a) 30, (b) 60, (c) 90, (d) 120, and (e) 180 minutes
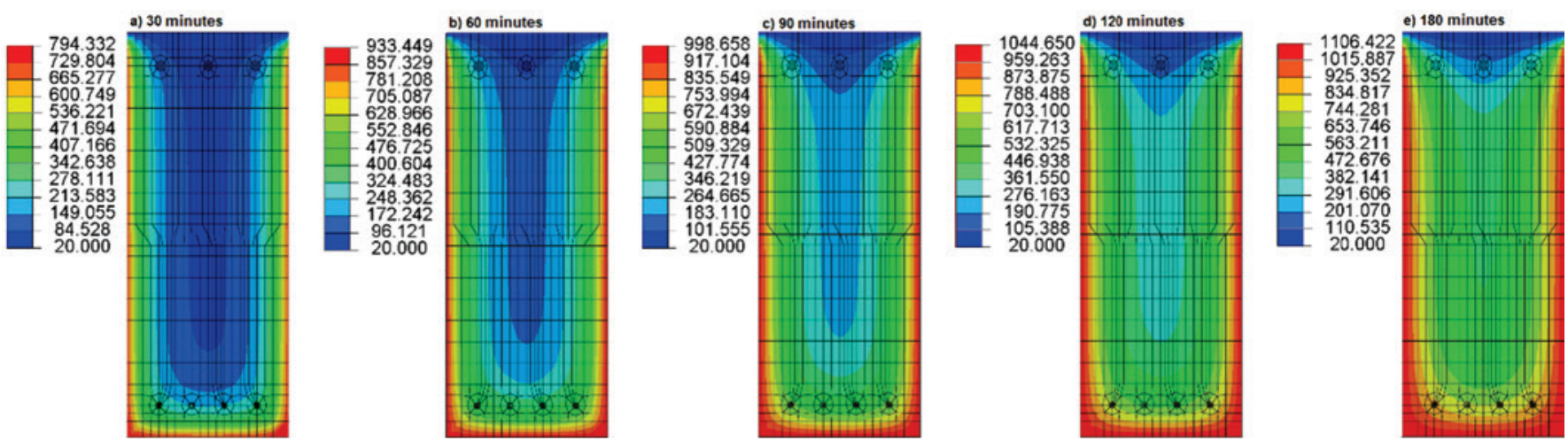

Figure 8

Isotherm B2-II for ratings of (a) 30, (b) 60, (c) 90, (d) 120, and (e) 180 minutes
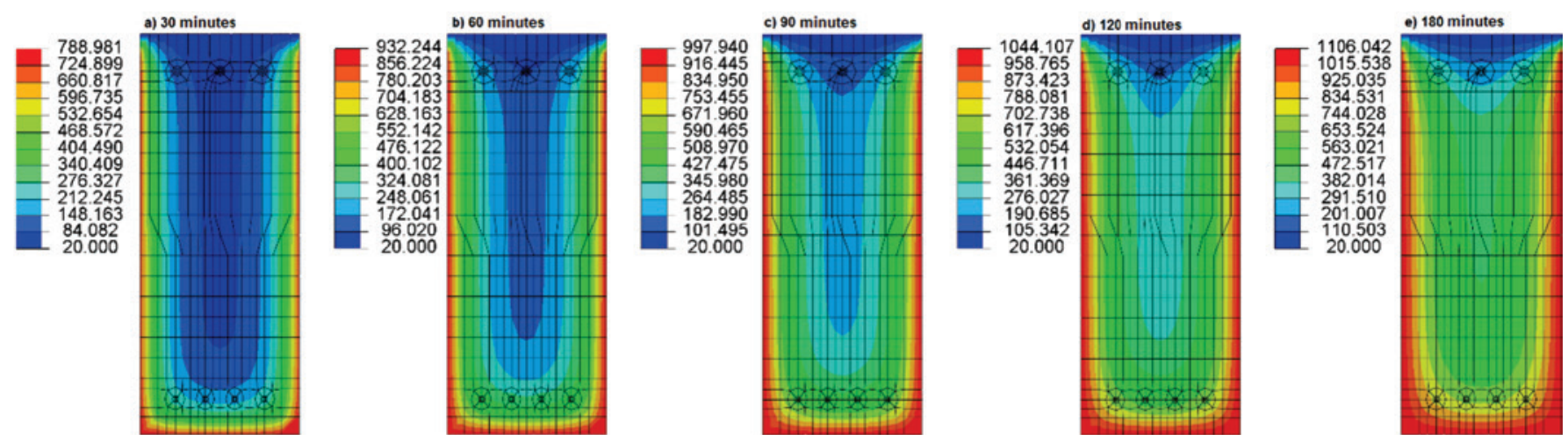

\section{Figure 9}

Isotherm B2-III for ratings of (a) 30, (b) 60, (c) 90, (d) 120, and (e) 180 minutes
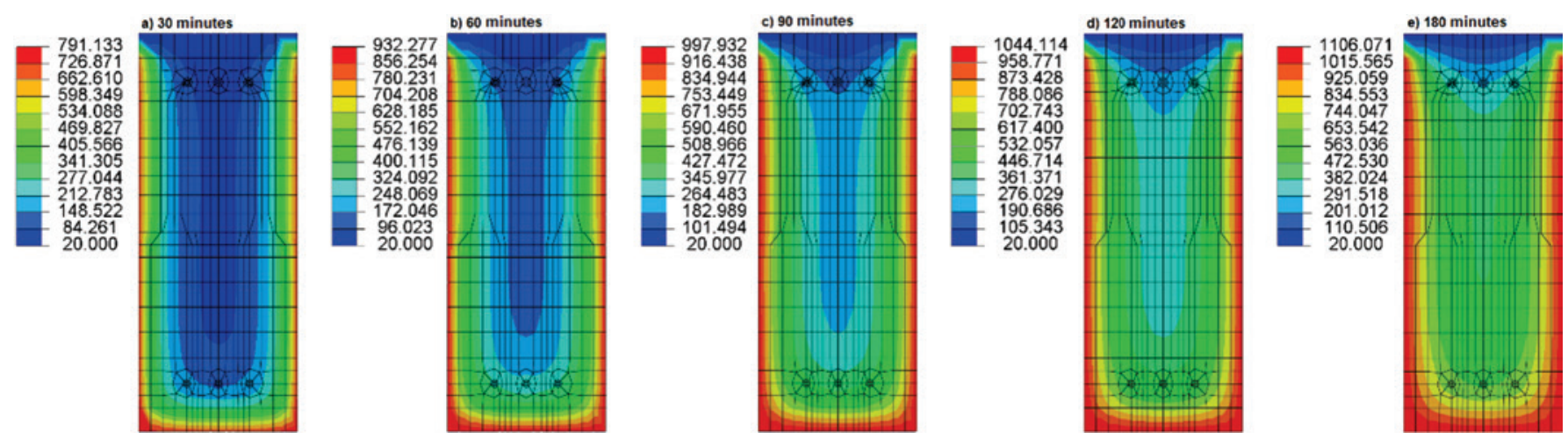

Figure 10

Isotherm B2-IV for ratings of (a) 30, (b) 60, (c) 90, (d) 120, and (e) 180 minutes 
parameter, as it was imagined, but on thermophysical properties of concrete and geometry of the structural element as well. The cover thickness of the reinforcements of the set of beams analyzed in this study caused more impact than the diameter of longitudinal reinforcements. This was predictable, since the thickness $\mathrm{C} 1$ theoretically increases more as a result of the variation of cover thicknesses set on the exposure classes rather than from the increase of diameter. Additionally, the top reinforcements did not lose strength, taking in mind the little variation of its temperatures attained due to the thermal protection provided by the slab and the assumption that the top face of the slab was adiabatic. The authors consider such simplification acceptable because the lateral cover thickness of these reinforcements, ensured by the slab, is infinite. Regarding the adiabatic top surface, it was admitted that the fire would concentrate in a single room, heating only the perimeter of the slab that is exposed to fire conditions without spreading to adjacent rooms. Therefore, the slab was considered to have met compartmentalization requirements.

These results defined the TRF of beams B1-I, B1-II, B1-III, BI-IV, B2-I, B2-II, B2-III and B2-IV, which were 60, 90, 90, 120, 90, 90, 120 and 120 minutes respectively.

\subsection{Comparison between tabular and simplified methods}

Table 6 comprises the comparison of both methods. The simplified method presented higher TRF for six elements, that is, in $75 \%$ of cases, whereas the TRF obtained in the other the $25 \%$ was the same for both models. This demonstrates that the simplified method yields better results for the design and results in pieces that are more appropriate for this type of analysis, although not in the totality of cases analyzed. The fact that none of the elements presented lower TRF for the simplified method within the calculation models adopted indicates that the tabular method yields reliable conservative results for the case in question. These results must still be proven through larger samplings that analyze a wider set of design conditions, though. Moreover, the simplified method grants more freedom to the designer, allowing assessments that vary diameter of reinforcements or concrete strength, which would not be possible through the tabular method.

As for the application time, the tabular method is simpler and faster to be applied, while the simplified method required more complex analyses with specific software programs to determine temperature distribution along sections of the element and then assess the bending moment via the application of strength reduction factors. Yet, this longer time spent on the analysis can be used to optimize the design and reduce costs related to consumption of materials, although such fact still has to be proven by a wider set of real design situations.

\section{Conclusions}

This study aimed to compare the tabular and simplified methods of assessment proposed by NBR 15200 [2] applied to two reinforced concrete beams in different conditions. The criteria for structural analysis at high temperatures were applied to an isostatic beam and a hyperstatic beam measuring $20 \mathrm{~cm} \times 50 \mathrm{~cm}$, dimensioned at room temperature for durability design classes I to IV of

\section{Table 6}

Comparison of FRR from tabular and simplified methods

\begin{tabular}{ccc}
\hline Element & $\begin{array}{c}\text { Tabular FRR } \\
\text { (minutes) }\end{array}$ & $\begin{array}{c}\text { Simplified FRR } \\
\text { (minutes) }\end{array}$ \\
\hline Beam B1 - I & 60 & 60 \\
Beam B1 - II & 60 & 90 \\
Beam B1 - III & 60 & 90 \\
Beam B1 - IV & 90 & 120 \\
Beam B2 - I & 60 & 90 \\
Beam B2 - II & 60 & 90 \\
Beam B2 - III & 90 & 120 \\
Beam B2 - IV & 120 & 120 \\
\hline
\end{tabular}

NBR 6118 [1]. Based on designs at room temperature and assuming that analyses at high temperatures regard a verification, the aforementioned beams were assessed for safety in fire conditions through the methods of NBR 15200 [2].

- The fire-resistance time (TRF) of the $20 \times 50 \mathrm{~cm}$ beams were higher for exposure classes III and IV of NBR 6118 [1] for both methods due to the higher thickness of the $\mathrm{C} 1$ coefficient, as expected;

- The staticity of the beam turned out to be influent as it tended to increase TRF by 30 minutes. This difference is a consequence of the redistribution of moments that took place when the continuous beam was exposed to fire;

- The parameter of highest impact on fire resistance of the beam was the temperature of reinforcements for both methods, which supports the methodology of the tabular method as it considers the width of the cross-section and the distance between the center of the reinforcements and the face exposed to fire as assessment parameters;

- The TRF yielded by the simplified method was higher than the one of the tabular method for beams B1-II, B1-III, B1-IV, B2-I, B2-II and B2-III, which correspond to $75 \%$ of cases. The TRF obtained through the simplified method for these beams was 30 minutes higher than the TRF obtained through the tabular method. Such difference between methods is due to the simplified method requiring the measurement of reinforcement temperatures every time period and the recalculation of the bending moment of the element according to this temperature, hence increasing its precision;

- In spite of requiring a more detailed analysis of the element, the simplified method yields higher TRF than the tabular method;

- As a suggestion, larger samplings should be conducted, mainly those covering other conditions and scenarios of design for these elements. The experimental evidence of results is part of the next steps of this study, which shall be conducted in the horizontal furnace of the fire-safety laboratory of itt Performance at Unisinos.

\section{References}

[1] ASSOCIAÇÃO BRASILEIRA DE NORMAS TÉCNICAS (ABNT). NBR 6118: Projeto de estruturas de concreto Procedimento. Rio de Janeiro, 2014. 
[2] ASSOCIAÇÃO BRASILEIRA DE NORMAS TÉCNICAS (ABNT). NBR 15200: Projeto de estruturas de concreto em situação de incêndio. Rio de Janeiro, 2012.

[3] ASSOCIAÇÃO BRASILEIRA DE NORMAS TÉCNICAS (ABNT). NBR 14432: Exigências de resistência ao fogo de elementos construtivos de edificações - Procedimento. Rio de Janeiro, 2001.

[4] KODUR, V., Properties of Concrete at Elevated Temperatures. ISRN Civil Engineering, V. 2014, p. 1-15, 2014.

[5] GEORGALI, B.; TSAKIRIDIS, P.E. Microstructure of firedamaged concrete. A case Study. Cement and Concrete Composites, v. 27, n. 2, p.255-259, 2005.

[6] COSTA, C.N.; SILVA, V. P. Estruturas de concreto armado em situações de incêndio. In: JORNADAS SUL-AMERICANAS DE ENGENHARIA ESTRUTURAL, 30, 2002, Brasília. Proceedings... Brasília: FINATEC/UnB, 2002. 1 CD-ROM.

[7] COSTA, C.N. Dimensionamento de elementos de concreto armado em situação de incêndio. Thesis (Ph.D. in Civil Engineering). Polytechnic School, Universidade de São Paulo: São Paulo, 2008.

[8] ALBUQUERQUE, G.B.M.L.; SILVA, V.P. Dimensionamento de vigas de concreto armado em situação de incêndio por meio gráfico. IBRACON - Revista Ibracon de Estruturas e Materiais, v.6, n.4, 2013.

[9] BOLINA, F.L. Avaliação experimental da influência dos requisitos de durabilidade na segurança contra incêndio de protótipos de pilares pré-fabricados de concreto armado. Dissertation (Master's Degree). Universidade do Vale do Rio dos Sinos - UNISINOS: São Leopoldo, 2016.

[10] KLEIN JR, O. Pilares de concreto armado em situação de incêndio submetidos à flexão composta. Dissertation (Master's Degree). Universidade de São Paulo, 2011.

[11] CHUDYBA, K.; SEREGA, S. Structural Fire Design Methods for Reinforced Concrete Members. Institute for Building Materials, Faculty of Civil Engineering, Cracow University of Technology, 2013.

[12] DWAIKAT, M. B.; KODUR, V. K. R. Response of Restrained Concrete Beams under Design Fire Exposure. 1408, Journal of Structural Engineering. 2009.

[13] INTERNATIONAL ORGANIZATION FOR STANDARDIZATION (ISO). ISO 834-1: Fire-resistance tests - Elements of building construction - Part 1: General requirements. Geneva, 1999

[14] BOLINA, F.; TUTIKIAN, B. Especificação de parâmetros da estrutura de concreto armado segundo os preceitos de desempenho, durabilidade e segurança contra incêndio. Revista Concreto e Construções, n. 76, p. 24-38, 2014.

[15] MOHAMMAD, M. R.; NISHIYAMA, M. Fire response of exterior reinforced concrete beam-column assemblages. Fire Safety Journal, v. 91, p. 498-505, 2017.

[16] XU, Q.; HAN, C.; WANG, Y. C.; LI, X.; CHEN, L.; LIU, Q. EXperimental and numerical investigations of fire resistance of continuous high strength steel reinforced concrete T-beams, Fire Safety Journal, v. 78, p. 142-154, 2015.

[17] SILVA, V. P. Projeto de estruturas de concreto armado em situação de incêndio conforme ABNT NBR 15200: 2012. Blucher: São Paulo. 2 ed. 2016.
[18] ARAÚJO, J. M. Curso de concreto armado. Editora Dunas: Rio Grande. 4 ed. 2014.

[19] SILVA, V. P. Dimensionamento de vigas de concreto armado em situação de incêndio. Aprimoramento de algumas recomendações do Eurocode. IBRACON - Revista Ibracon de Estruturas e Materiais, v.4, n.2, 2011.

[20] ALBUQUERQUE, G. B. M. L.; SILVA, V. P. Dimensionamento de vigas de concreto armado em situação de incêndio por meio gráfico. IBRACON - Revista Ibracon de Estruturas e Materiais, v.6, n.4, 2013.

[21] EUROPEAN COMMITTEE FOR STANDARDIZATION (EN). BS EN 1992: Design of concrete structures - Part 1-2: General rules - Structural fire design: Eurocode 2. Brussels, British Standards Institution: 2004. 